\title{
Justice Holmes and the Question of Race
}

\section{Thomas Halper*}

\begin{abstract}
Notwithstanding his youthful dalliance with abolitionism, Holmes' votes and opinions in Supreme Court cases involving race reveal a stubborn indifference to discrimination on a range of issues. Whether this reflects a cold personal aloofness, a preoccupation with life as struggle, a commitment to judicial restraint or merely an insensitivity pervading the enlightened opinion of the day, his performance will continue to stain his reputation.
\end{abstract}

\section{KEYWORDS}

Holmes, Race, Segregation, Giles v. Harris

\section{CONTENTS}

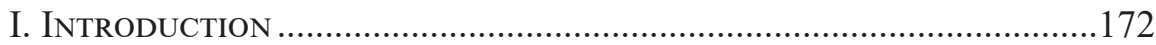

II. VoTING RIGHTS .................................................................... 176

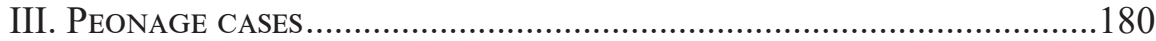

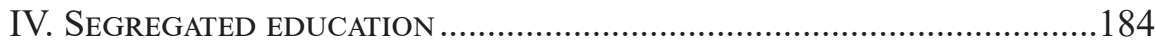

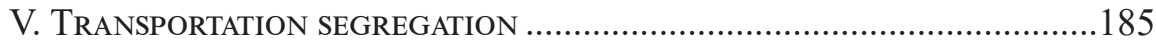

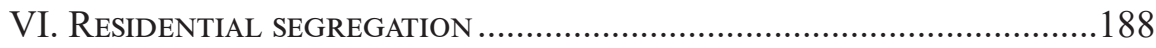

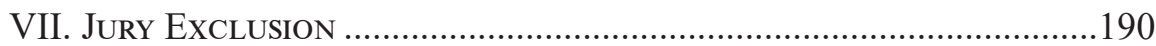

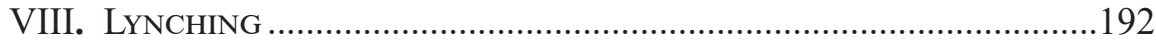

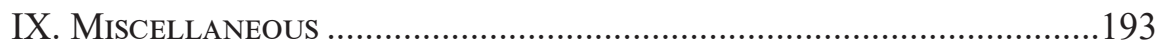

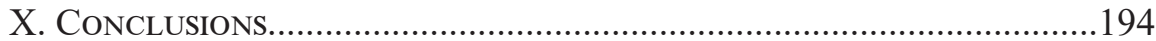

Baruch College \& the CUNY Graduate Center

My thanks to Rita Ormsby, who, so generous with her time and ingenuity, again was invaluable in supplying me with essential material. 


\section{INTRODUCTION}

Born into a life of intellectual and social privilege, where "the flowering of New England was almost a family affair," Oliver Wendell Holmes, Jr., as a young man was a bit of an idealist. As the nation was careening toward what William $\mathrm{H}$. Seward was famously to call an "irrepressible conflict" between slavery and freedom, ${ }^{2}$ Bostonians in the Holmes' circle immersed themselves in the question of race. Holmes' mother, normally reserved, was emphatic in denouncing slavery as evil and in lauding its antidote, abolitionism. His father, on the other hand, a renowned essayist, dean of the Harvard Medical School, and one of the nation's most prominent public intellectuals, disapproved of slavery but regarded it as a "physical act" to be accepted "to the minimum consistent with our existence as a united people." 3 Some members of his monthly Saturday Club, however, like Hawthorne ${ }^{4}$ and especially Emerson, ${ }^{5}$ were committed abolitionists, and bright, young Holmes, who often mixed with his elders, ${ }^{6}$ perhaps also felt their influence.

Years later, Holmes recalled that "in my day I was a pretty convinced abolitionist and was one of a little band intended to see [abolitionist] Wendell Phillips through if there was a row after the meeting of the Anti-Slavery Society just before the war." His closest friend at Harvard, Penrose Hallowell, whom he called "the most generously gallant spirit [and] the greatest soul I ever knew," had volunteered for the underground railroad. ${ }^{9}$ Holmes could easily have avoided service in the Civil War with a \$300 payment his family could have afforded without difficulty, but, encouraged by his mother, he withdrew from Harvard and enlisted. ${ }^{10}$

Philip Kurland, Portrait of a Justice as a Young Man, 25 U. CHI. L. Rev. 206, 208 (1957).

William H. Seward, The Irrepressible Conflict: A Speech by William Henry Seward Delivered at Rochester, Monday October 25, 1858 (1860).

3 Oliver Wendell Holmes, Sr., Oration: The Pilgrims of Plymouth, in 2 New Eng. Soc. Orations: Addresses, Sermons and Poems Delivered Before the New Eng. Soc. in THE City OF N.Y., 1820-1885 297, 296 (Cephas \& Evelyn Warner Brainerd eds., 1901). Holmes, Sr. considered blacks "the half-filled outlines of humanity." Id. at 298.

4 Celebrating the outbreak of the Civil War, Hawthorne wrote that "it is delightful to share in the heroic sentiment of the time." Horatio Bridge, Personal Recollections of Nathaniel HaWtHORNe 168 (1893).

5 Looking back many years later, Holmes wrote that "the only firebrand of my youth that burns as brightly as ever is Emerson." 1 Holmes-POLLOCK LeTters: THE CORRESPONDENCE of Mr. Justice Holmes ANd Sir Frederick Pollock, 1874-1932 264 (1941). See generally, Adam H. Hines, Ralph Waldo Emerson and Oliver Wendell Holmes, Jr.: The Subtle Rapture of the Postponed Power, 44 J. SuP. Cт. Hist. 39 (2019). Louis Menard thought that Holmes' "posture of intellectual isolation [was] essentially Emersonian." Louis Menand, The Metaphysical Club: A Story of Ideas in America 68 (2002).

6 On young Holmes as a conversationalist, see Peter Gibian, Oliver Wendell Holmes AND THe Culture of CONVERSATION 59-212 (2001).

72 Holmes Laski Letters: The Correspondence of Mr. Justice Holmes and Harold J. LASKI 893 (Mark DeWolfe Howe ed., 1953).

8 Holmes-Einstein Letters: Correspondence of Mr. Justice Holmes and Lewis EINSTEIN, 1903-1935 90 (James B. Peabody ed., 1964).

9 Norwood P. Hallowell, Selected Letters and Papers of N.P. Hallowell 25 (1963).

10 On the psychological importance of his enlistment, see Saul Touster, In Search of Holmes from Within, 18 VAND. L. Rev. 437 (1965). 
When he learned that his unit would be based in Boston, he transferred to another that saw combat, the Twentieth Massachusetts Voluntary Infantry, which suffered more combat deaths than nearly any other unit in the army. A Boston abolitionist, recalling the euphoria of the day, said that "it was as if one had learned to swim in air, and were striking out for some new planet."11

Yet at a Memorial Day speech nearly twenty years after the war, Holmes remembered thinking only that "slavery had lasted long enough," 12 possibly the most tepid condemnation imaginable from a writer whose "words were feathered arrows, that carried to the heart of the target, from a mind that searched and saw."13 The "issue of slavery [had] captured Holmes' attention" 14 and sent him on to war, but the abolitionist commitment was not rooted in personal experiences with slaves or free blacks nor did it even induce him to avoid relationships with Southerners at Harvard from slave owning families. He later recalled of his generation that "our hearts were touched with fire," 15 but in truth it was a kind of kindling that quickly burned itself out.

Nonetheless, Holmes' war experiences were transformative, leaving him with "more cold steel in his make-up. "I "I am not the same man (may not have quite the same ideas)," he wrote his mother after the Overland Campaign. ${ }^{17} \mathrm{He}$ was seriously wounded three times, very nearly died from dysentery, and saw his best friend, Henry Abbott, killed in action. The ignorance and stupidity of some of his commanding officers - an ignorance and stupidity that many soldiers and friends of his paid with their lives - left him shaken. "I see [a] youthful lieutenant . . . when I looked down the line," he recalled. "The advance was beginning, we caught each other's eye and saluted. When next I looked, HE WAS GONE." ${ }^{18}$ The Battle of Ball's Bluff made an especially heavy imprint. Union soldiers were surrounded on three sides by Confederates and on the fourth by a sheer cliff overlooking a swift flowing river. The result was a massacre that left Holmes shot and contemplating taking poison his father had given him, if facing death. "I made up my mind to die," he wrote his mother, but having passed the test for combat valor, he boasted, "I felt and acted very well and did my duty, I am sure." ${ }^{\prime 19}$ Everywhere were men struggling to fight and to survive, all for no real purpose, and randomness so often seemed to determine life, death, injury. At one point in the war, he wrote home, "As you go through the woods you stumble constantly, and if after dark perhaps tread on the swollen bodies already fly blown and decaying, of men shot in the head, back, or bowels." 20

\footnotetext{
11 Thomas W. Higginson, Cheerful Yesterdays 249 (1898).

Oliver Wendell Holmes, JR., SPeeches 1 (1891).

Francis Biddle, Mr. Justice Holmes 2 (1942).

G. E. White, Oliver Wendell Holmes, Jr. 10 (2006).

HoLMES, supra note 12, at 11.

16 Harry C. Shriver, Oliver Wendell Holmes: Lawyer, 24 A.B.A.J. 157 (1938). But cf., Mark D. Howe, Oliver Wendell Holmes, Jr.: The Shaping Years, 1841-1870, 274 (1957).

17 Oliver W. Holmes, JR., Touched With Fire: Civil War LetTers and Diary Of Oliver Wendell Holmes, JR. 129 (Mark D. Howe ed., 1946).

18 Oliver Wendell Holmes, JR., Speeches 6 (1913).

19 Holmes, supra note 17 , at $13,17-8$.

$20 \quad I d$. at 51.
} 
By the time of the Emancipation Proclamation in 1863, which his mother hailed emotionally, he dismissed her high spirits and spoke of the fighting that lay ahead. In 1864, he wrote home that he had "felt for some time that I didn't any longer believe in this being a duty." ${ }^{21}$ He had had enough of the war, perhaps suffering from undiagnosed post-traumatic stress disorder. ${ }^{22}$ By this time, he had drifted away from Hallowell and become close friends with Abbott, a courageous soldier ("In action he was sublime"23), who flaunted his contempt for abolitionists and blacks. He recalled Abbott's "splendid coolness," 24 and later celebrated a soldier's faith "to throw away his life in obedience to a blindly accepted duty, in a cause which he little understands, in a plan of a campaign of which he has little notion, under tactics of which he does not see the use. ${ }^{25}$ But this was not his way. He wrote his mother that "I can no longer endure the horrors of the line. . . . war demoralizes me. . . now I honestly think the duty of fighting has ceased for me." 26 When his three year enlistment ended, he returned to Boston. "I started in this thing as a boy," he wrote, "and am now a man."27

Back home, Holmes found that his idealism had peeled away like bruised skin off a fruit. "The law had broken down in America," wrote Edmund Wilson, and "the Constitution had gone to pieces. It was impossible for an honest man of Holmes' probing intelligence to pretend that the law was a sacred code, which had simply to be read correctly." 28 Louis Menand thought that the war had caused Holmes to "lose his belief in beliefs," 29 but that is not exactly so, for what remained was a belief, really a fixation, on struggle. As Holmes, Sr. had observed, "Every now and then a man's mind is stretched by a new idea or sensation and never shrinks back to its former dimensions." ${ }^{30}$ Holmes, Jr.'s new idea, as he expressed it in an 1873 article, was that "the struggle for life [is] the law of human existence," 31 an idea that seemed validated by his war experiences and the now potent theory of evolution.

But where the typical Social Darwinists of his day imagined that the struggle led inexorably to the improvement of the race, Holmes believed that the randomness of life meant that the results might be negative as well as positive..$^{32} \mathrm{In}$ his eyes, the optimists' assumption was simply an act of faith, bereft of evidence. All one could say for certain was that struggle led to more struggle. Beyond that, it was hard to know where it led. But Holmes did not collapse in existential despair. For him, as for Nietzsche, the discovery of truth may be beyond human capacity, but we can

\footnotetext{
Id. at 122 .

22 Holmes wrote his parents that "Many a man has gone crazy since the campaign begun from the terrible pressure on body and mind." $I d$. at 150.

Id. at 41 .

25 Oliver W. Holmes, JR. The Soldier's Faith, in Speeches 56, 59 (1896).

26 Supra note 17, at 143.

27 Id. at 142.

28 Edmund Wilson, Patriotic Gore 765 (1962).

29 MENARD, supra note 5, at 4.

30 Oliver W. Holmes, SR., The Autocrat of the Breakfast Table (1853).

31 Oliver W. Holmes, Jr., The Gas Stokers' Strike, 7 Am. L. Rev. 558, 573.

32 In his notorious eugenics opinion, Holmes ruminated on the fact that "the public welfare may call upon the best citizens for lives," leaving the less fit to survive. Buck v. Bell, 274 U.S. 200, 207 (1927).
}

24 Id. 
at least honor the will to struggle for individual autonomy and greatness. ${ }^{33}$ For Holmes, this meant launching his legal career with enormous drive and ambition. Toward the world, though, he looked with his famous (or notorious) detachment: "If my fellow citizens want to go to hell I will help them," he wrote a friend. "It's my job." 34

By the time he was a famous judge, Holmes' abolitionism had quite evaporated. What remained was a distaste for its intensity and moral certainty. Indeed, he admitted that he "came to loathe in the abolitionists the conviction that anyone who did not agree with them was a knave or fool." ${ }^{35}$ He derided them for putting "their ideals and prophecies with the slight superior smile of the man who is sure that he has the future. . . I can only say that the reasoning seems to me inadequate." ${ }^{\prime 36}$ They seemed to him like the temperance advocates of prohibition. ${ }^{37}$

By this time, too, the Civil War's goal of freedom for the slaves had in peace time turned to ashes. Legally required racial segregation, augmented by violence and terror, had enshrined white supremacy in the South and left the black population in poverty and subjugation. Most whites in the North hardly seemed to notice, but not Holmes. To complaints about the Sacco and Vanzetti trial, for example, he answered, "If justice is the interest why do they not talk about the infinitely worse cases of the blacks?" 38 And again, "A thousand fold worse cases of negroes come up from time to time but the world does not worry over them." ${ }^{39}$

Holmes' service on the Supreme Court, particularly in the first two decades or so, coincided with an explosion of race riots that inflicted heavy losses in life and property, almost exclusively on blacks. In the South, riots took place in Pierce City, Missouri (1901); Statesboro, Georgia (1904); Atlanta (1906); Houston (1917); Elaine, Arkansas; Jenkins county, Georgia; Charleston; Longview, Texas; Washington; Norfolk; Knoxville; and Annapolis (1919); Ocoee, Florida (1920); Tulsa (1921); Perry, Florida (1922); and Rosewood, Florida (1923). At the same time, rioting also occurred in the North at Denver (1901); Evansville, Indiana (1903); Springfield, Ohio (1904 and 1906); Greensburg, Indiana (1906); Springfield, Illinois (1908); East St. Louis, Illinois (1917); and Indianapolis and Omaha (1919). DuBois had predicted that the "problem of the twentieth century is the problem of the color line." ${ }^{40}$ Holmes might have been vaguely aware of that. Consider his voting and opinion record on the race related cases decided during his tenure on the Supreme Court.

\footnotetext{
33 On Holmes and Nietzsche, see Seth Vannatta \& Allen Mendenhall, The American Nietzsche? Fate and Power in the Pragmatism of Justice Holmes, 85 UMKC L. REV. 187, esp. 193-202 (2016).

341 Holmes-LASKi, supra note 7, at 249.

2 Id. at 1291.

2 Id. at 948.

${ }^{37} 2$ Holmes-Pollock, supra note 5, at 253.

2 HoLMES-LASKI, supra note 7, at 975.

2 Id. at 974.

40 W.E.B. DuBois, The Souls of Black Folk xv (1903).
} 


\section{VoTING RIGHTS}

Giles v. Harris (1903) concerned a class action suit brought by Jackson Giles, the head of the Colored Men's Suffrage Association of Alabama, who alleged that blacks had been disenfranchised by the state in violation of the Fourteenth and Fifteenth Amendments. ${ }^{41}$ Alabama's 1901 constitution provided that persons registered to vote before 1903 were registered for life, ${ }^{42}$ while those registered after that date had to meet, in Holmes' words, "severe tests ... which would exclude, perhaps a large part of the black race. . . as part of a general scheme to disenfranchise them." Giles sought an injunction to permit blacks "to obtain the permanent advantages of registration as of a date before 1903," 44 that is, to compel Alabama to register him and other qualified blacks. Alabama raised a series of technical mootness and jurisdictional issues that would have allowed the Court to bypass the merits of the case, but the Court chose to reach the merits.

Holmes, speaking for a five-four majority, refused to grant relief. If the "whole registration scheme of the Alabama constitution is a fraud upon the Constitution of the United States," he asked, "how can we make the Court a party to the unlawful scheme by accepting it and adding another voter to its fraudulent lists?"45 Even if the Court issued an order, he added, "the great mass of the white population intends to keep the blacks from voting." Hence, if "the conspiracy and the intent exist, a name on a piece of paper will not defeat them." ${ }^{46}$ Relief would require the Court "to be prepared to supervise the voting," ${ }^{47}$ which lay far beyond its powers. Instead, relief "from a great political wrong, if done, as alleged, by the people of a state and the state itself, must be given by them or by the legislative and political department of the United States." 48

James v. Bowman (1903) concerned Henry Bowman, a white Kentuckian, who was indicted for preventing blacks from voting in a congressional election by means of bribery and intimidation. Justice Brewer, born into an abolitionist family and an abolitionist as a young man, ${ }^{49}$ speaking for a six-two majority, observed that the Fifteenth Amendment required federal or state action, and so the congressional act at issue that was passed under its authority must be directed at federal or state action, too. But here he found only individual action. ${ }^{50}$ The fact that the offense alleged concerned a congressional election was insufficient to implicate the federal government, which was otherwise not involved in the offense.

${ }_{41}$ The cost and legal representation were secretly arranged by Booker T. Washington. August Meier, Toward a Reinterpretation of Booker T. Washington, 23 J. SoutH. Hist. 220 (1957).

$42 \quad$ Ala. Const. art. $8, \S 187$.

43 Giles v. Harris, 189 U.S. 475, 482 (1903).

$44 \quad I d$. at 484.

45 Id. at 486

$46 \quad I d$. at 488.

47 Id.

48 Id. Brewer and Harlan, dissenting separately, maintained that courts can give relief in such cases, though they did not focus on the race issue that led Holmes to conclude that this was problematical.

49 J. Gordon Hylton, The Judge Who Abstained in Plessy v. Ferguson: Justice David Brewer and the Problem of Race, 61 Miss. L. J. 315, 322-26 (1991).

$50 \quad$ James v. Bowman, 190 U.S. 127, 139 (1903). 
Guinn and Beal v. United States (1915) focused on an amendment to the Oklahoma Constitution, adopted three years after the state was admitted to the Union, that required persons not entitled to vote before 1866 to pass a literacy test. Chief Justice White, speaking for a unanimous Court, acknowledged that states could impose literacy tests, but held that restricting it to persons who had not been eligible to vote prior to the Fifteenth Amendment clearly was aimed at disenfranchising blacks, and thus conflicted with the Fifteenth Amendment. Oklahoma had contended that states were empowered to set voting standards and that its amendment was not directed at blacks. But White, a former governor of Louisiana who had fought for the Confederacy, asked, "how can there be any room for any serious dispute concerning the repugnancy" of the Oklahoma amendment? ${ }^{51}$ Such grandfather clauses, he concluded, were invalid. ${ }^{52}$

Myers v. Anderson (1915) concerned an Annapolis, Maryland law that provided three possible voting requirements: that the citizen owned at least $\$ 500$ worth of assessed property, that he be a naturalized citizen or their son, or that his descendants had been entitled to vote before 1868. Anderson, who was black, said that he did not own sufficient property nor was he a naturalized citizen, and he had been unable to vote before 1868, when the Fifteenth Amendment barred states from disenfranchising him because he was black. Thus, he contended that the law effectively denied him the vote on account of his race, in violation of the Fifteenth Amendment. Annapolis replied that the Fifteenth Amendment was not involved because each of the three requirements allowed some blacks to vote and disallowed some whites.

White, again speaking for a unanimous Court, held that the 1868 provision clearly violated the Fifteenth Amendment, ${ }^{53}$ and that the other two requirements also must be dropped because together they meant that a native born citizen had to meet a property qualification, while a naturalized citizen did not, an "incongruous result" ${ }^{\prime 4}$ that made no sense.

United States v. Mosely (1915) concerned an Oklahoma county election board member, Mosely, who conspired to fail to count votes from precincts with a sizable number of black voters. Congress had made it unlawful to conspire to prevent citizens from the enjoyment of constitutional or statutory rights. ${ }^{55}$ Mosely argued that the law, which had originally targeted the Ku Klux Klan, did not expressly apply to voting.

Holmes, writing for a seven-one majority thought it was obvious that words that banned conspiracies to prevent blacks from voting also covered not counting their votes. ${ }^{56}$ The Klan might "have passed away," but regardless of what Congress intended in the law, "we cannot allow the past so far to affect the present as to deprive citizens" of their legal rights." ${ }^{57}$ In the course of his opinion, he dismissed a technical argument tying a provision of the statute to a provision of an earlier statute. ${ }^{58}$

\footnotetext{
Guinn v. United States, 238 U.S. 347, 363 (1915).

$I d$. at 368. Oklahoma then passed another grandfather clause law that remained in effect until 1939, when it was struck down in Lane v. Wilson, 307 U.S. 268 (1939).

53 Myers v. Anderson, 238 U.S. 368, 380 (1915).

54 Id. at 382.

55 Pub. L. No. 60-350, 35 Stat. 1088, 1092 (1909).

56 United States v. Mosley, 238 U.S. 383, 386 (1915).

$57 \quad I d$. at 388.

$58 \quad I d$. at $386-87$.
} 
Love v. Griffith (1924) involved white primary elections in Texas. Around the turn of the century, the primary emerged in the North as a Progressive reform aimed at curbing the influence of party bosses. In the South, where the Democratic party effectively monopolized elections, the primary served a different purpose. By confining the primary vote to white Democrats, it disenfranchised black Democrats, at best leaving them free to vote in an uncontested general election.

The Houston Democratic Executive Committee, on the theory that the party is a private organization like a bowling league, barred blacks from voting in the local Democratic primary. C.N. Love, a black Houston journalist and a Democrat, sought an injunction to forestall the election on the ground that the committee had violated his Fifteenth Amendment right against racial exclusion in voting. Love lost, and was ordered to pay court costs.

Holmes, speaking for a unanimous Court, conceded that Love's complaint could "present a grave question of constitutional law," but observed that the committee's action covered only "a single election," and that as the election had taken place a year earlier, "the cause of action had ceased to exist." ${ }^{59}$ Thus, mootness saved the Court from confronting the issue on its merits - Holmes was unimpressed by the argument that court costs remained a live issue - and no dicta were offered on the constitutional question.

Nixon v. Herndon (1927) also concerned a Texas white primary. Nixon, a black Democrat, was prevented from voting in a Democratic primary by a state statute, ${ }^{60}$ and contended that this violated both his Fourteenth and Fifteenth Amendment rights. Texas maintained that the issue was political, and thus not suitable for judicial determination.

Holmes, again writing for a unanimous Court, dismissed the state's argument as "little more than a play upon words" ${ }^{61}$ because political actions that result in private damages may be resolved in lawsuits. It was not necessary to reach the Fifteenth Amendment issue, he said, as "it seems to us hard to imagine a more direct and obvious infringement of the Fourteenth. ... [I]t is too clear for extended argument that color cannot be made the basis of a statutory classification affecting the right set up in this case." 62

Nixon begs to be compared with Love. Both rulings are brief - Nixon is three pages and Love three paragraphs - and both betray a tone so dismissive as to suggest that the losing litigants wasted the Court's valuable time. Yet what is jarring is that in Love the dismissiveness is directed against a plaintiff opposing a white primary, and in Nixon one supporting it. Also odd was Holmes' citing in Nixon his earlier opinion in Giles in support of his remark that political matters may pose justiciable issues, when that is precisely what he declined to do in that case.

In four of the six cases involving voting rights, Holmes supported the black plaintiffs, but in the two most important cases, his record is mixed. On the one hand is Giles, "Surely one of the most momentous decisions in United States Supreme Court history." ${ }^{3}$ If the voting scheme is invalid, he asks, how can we accept it

Love v. Griffith, 266. U.S. 32, 34 (1924).

(1925) Tex. Rev. Civ. Stat. 3107.

Nixon v. Herndon, 273 U.S. 536, 540 (1927).

Id. at 541.

63 Richard H. Pildes, the Canon(s) of Constitutional Law: Democracy, Anti-Democracy and the Canon, 17 Const. Comment. 295, 297 (2000). 
and add new voters to it? But Giles' point was that it was the exclusion of blacks that made the scheme invalid; by including them, it would become valid. Holmes' reference to a disappearing Klan was also hard to explain, as 1915 saw the release of The Birth of a Nation, by far the most popular silent movie ever produced, which glorified the Klan. ${ }^{64}$

Holmes also seemed intimidated by the fact that "the great mass of the white population" ${ }^{\circ 5}$ meant to disenfranchise blacks. Certainly, it was obvious that disenfranchisement was the purpose of the provision. The president of the Alabama constitutional convention had declared its goal to be "to establish white supremacy in the state," $" 66$ and black voter registration in Alabama had declined from 93\% in 1896 to $2.9 \%$ in $1902 .{ }^{67}$ Holmes acknowledged as much. The question was: how should the Court respond? Overcome with a sense of the Court's powerlessness, Holmes feared that an order to open the voting would be disobeyed, humiliating the Court and perhaps emboldening future litigants to flout its authority ${ }^{68}$ His assumption of overwhelming support for black exclusion, however, may be open to question. The constitution was adopted only because Black Belt counties voted overwhelmingly for it; the rest of the state rejected it. As the Black Belt counties had a large black population and would hardly have supported its own disenfranchisement, it was commonly believed that there had been widespread voter fraud. ${ }^{69}$

Holmes" decision, said to "wed legalism to realpolik," "cynical and disingenuous" avoidance of the constitutional question, ${ }^{71}$ and a "carte blanche to southern politicians." ${ }^{.72}$ Derrick Bell, one of the most prominent civil rights advocates of his day, thought the ruling amounted to "judicial abstention with a vengeance." Yet, Bell continued, "what alternative did Justice Holmes have available? [A] court's power to issue and enforce orders is limited to those orders that at least a substantial percentage of the people want or will permit to be carried out." ${ }^{\prime \prime 3}$ There was an alternative near at hand, however, though not a very satisfying

64 It was said that President Wilson viewed the movie at the White House, and proclaimed that it was "like writing history with lightning." Mark E. Benbow, Birth of a Quotation: Woodrow Wilson and Writing History with Lightning, 9 J. OF THE GILDED AGE \& Progressive Era 509, 528 (2010).

65 Giles, supra note 43, at 488.

66 Qtd. in Hunter v. Underwood, 471 U.S. 222, 229 (1985).

67 The standard history alleges that the point of the provision was to legalize and formalize black disenfranchisement that had heretofore been pursued in a more informal, ad hoc manner. Sheldon Hackney, Populism and Progressivism in Alabama 189-81 (1969).

68 That enlightened white sentiment in the North was untroubled by the decision is evident in the response of Harper's Weekly, which pointed to "new negro crime, by which is meant against white women, [which] is due to the notion of political and social equality implanted by the gift of suffrage." Recent Discussion of the Fifteenth Amendment, 47 HARPER's WEEKLY 1144 (July 11, 1903).

69 R. Volney Riser, Disenfranchisement, the U.S. Constitution, and the Federal Courts: Alabama's 1901 Constitutional Convention and the Grandfather Clause, 48 Am. J. Leg. Hist. 237 (2006).

70 Pildes, supra note 63, at 298.

71 William M. Wiecek, The Emergence of Constitutional Value: The First Century, 82 CHIKENT L. Rev. 233, 267 (2007).

72 Saul Brenner, Airbrushed Out of the Constitutional Canon: The Evolving Understanding of Giles v. Harris, 107 Mich. L. Rev. 853, 856 (2009).

73 Derrick A. Bell, Race, Racism, and American Law 40 (1980). Louise Weinberger 
one: accept Alabama's technical arguments, refuse to reach the merits, and deny giving discrimination the Court's tacit approval. This, of course, is exactly what Holmes chose to do in Love. Instead, he offered stunningly fatuous advice: look to the electorate or the political branches for relief; like his disciple, Frankfurter, ${ }^{74}$ he urged those wronged to seek redress from the very officials who benefited from the wrong. Holmes also implied that Giles could sue Alabama for damages, but when Giles took him up on that suggestion, Holmes joined seven other Justices in rejecting the claim. ${ }^{75}$

On the other hand, in Nixon v. Herndon Holmes struck down the white primary with a decisiveness rare at the time in racial discrimination cases. Thurgood Marshall believed that Holmes "felt that this decision laid the white primary to rest, " 76 but as it turned out, the battle continued for years. ${ }^{77}$ Yet it was Nixon that set the Court on the path that ended with the white primary's abolition.

\section{PeOnage CASES}

Peonage, involuntary servitude in payment of debt, was outlawed by Congress in 1867..$^{78}$ Among the first cases to arise under the law ${ }^{79}$ was Clyatt v. United States (1905), which raised the question as to whether peonage was barred by the Thirteenth Amendment's prohibition against involuntary servitude. Simon Clyatt captured at gunpoint a pair of black laborers who had worked for him and he claimed owed him money. With the help of a sheriff's deputy, he brought them from Florida to his workplace in Georgia. He pointed to a Florida law that provided for imprisonment under these circumstances and to Florida practice, where judges routinely ordered escaped black laborers to work off their debt. Despite these claims, Clyatt was convicted of violating Congress' Anti-Peonage Act. He appealed his conviction.

Justice Brewer, speaking for a unanimous Court, observed that the Thirteenth Amendment does not require state action, and so the law's applying to private conduct did not render it unconstitutional. But he could find "not a scintilla of

concluded that "deciding for Giles would have meant that big moral battles, as big as any in the Civil War, could be fought in the courts and in equity. This was the one device Holmes, from the beginning, had refused to consider. Weinberger, Holmes' Failure, 96 Мich. L. Rev. 691, 713 (1997). While she saw this as a failure of nerve, Holmes seems focused on the practical limits of the Court's power and the consequences of its orders being undone.

74 "It is hostile to a democratic system to involve the judiciary in the politics of the people," Frankfurter wrote, evidently considering it less hostile to permit gross legislative malapportionment. Colegrove v. Greene, 328 U.S. 549, 554 (1945).

75 Giles v. Teasley, 193 U.S. 146 (1904). Justice Day, "not unmindful of the gravity" of the issues raised, concluded that the Court had no right to review the state court's ruling. Id. at $166-67$.

76 Thurgood Marshall, The Rise and Collapse of the "White Democratic Primary," $26 \mathrm{~J}$. Negro Ed. 249, 251 (1957).

77 Nixon v. Condon, 286 U.S. 73 (1932); Grovey v. Townsend, 295 U.S. 45 (1935); Smith v. Allwright, 321 U.S. 649 (1944); Rice v. Elmore, 165 F. 2 d 387 (C.C.A. $4^{\text {th }}$, 1947); Terry v. Adams, 345 U.S. 461 (1953).

7814 Stat. 546.

79 William Wirt Howe, The Peonage Cases, 4 Colum. L. Rev. 279, 281 (1904). 
testimony to show that [the men] were ever theretofore in a condition of peonage." ${ }^{80}$ That is, Clyatt was charged with returning the men to a state of peonage, but the government had failed to demonstrate that their condition before they were captured was one of peonage. Thus, Brewer ordered a retrial, in the meanwhile releasing Clyatt from custody.

Hodges v. United States (1906) concerned black laborers in Arkansas, who had contracted to work for a lumber mill. Hodges and fourteen other white men told the laborers to stop working, and beat them and sent them away. The whites were then prosecuted for conspiring to intimidate persons to deprive them of their Thirteenth Amendment rights. Three of the defendants were convicted, and their appeal was heard by the Supreme Court.

Justice Brewer, writing for a seven-two majority, noted that the blacks claimed to have been mistreated because of their race, the mistreatment constituting a badge of slavery. It was, therefore, irrelevant from their perspective whether they personally had ever been slaves. Brewer found this argument fallacious. For one thing, the Thirteenth Amendment's prohibition against slavery "reaches every race," with "the Anglo-Saxon . . a as much within its compass as ... the African." 1 Thus, blacks could claim protection of the Thirteenth Amendment no more than anyone else, and the fact that none of them beaten by Hodges had "ever been themselves slaves or ... the descendants of slaves" ${ }^{\prime 2}$ became very relevant, indeed. The amendment, Brewer maintained, may have permitted Congress to deal with "incidents or badges of slavery," ${ }^{33}$ but this referred to legal acts only, and thus did not apply here. The Thirteenth Amendment "is not an attempt to commit that race to the care of the nation," ${ }^{84}$ and so Brewer advised blacks that "their best interests would be subserved [by] taking their chances with other citizens." $" 85$

Bailey v. Alabama (1908) concerned a black farm laborer, Alonzo Bailey, who was given an advance on his pay, but left work before his contract period ended and without paying what he owed. Alabama law presumed him guilty of fraudulent larceny, though he could rebut the facts; his leaving the job was prima facie evidence of his intent to defraud; the presumption might be overturned by evidence but not by the defendant's testimony. Bailey was detained, while a wellorganized effort was mounted on his behalf, involving Booker T. Washington, the United States attorney general, and prominent newspapers. Bailey contended that Alabama's peonage law violated the Thirteenth and Fourteenth Amendments, as well as Congress' Anti-Peonage Law, and asked that a writ of habeas corpus be granted, freeing him. President Roosevelt's Justice Department urged that Bailey be given a pre-trial release.

Holmes, writing for the seven-two majority, held that there "is no doubt" 86 the state can punish fraud. He conceded that "it appears that [Bailey] was held for trial on the statutory evidence and with no other proof of fraudulent intent," but insisted that Bailey was being punished for fraud and not for breach of contract. He

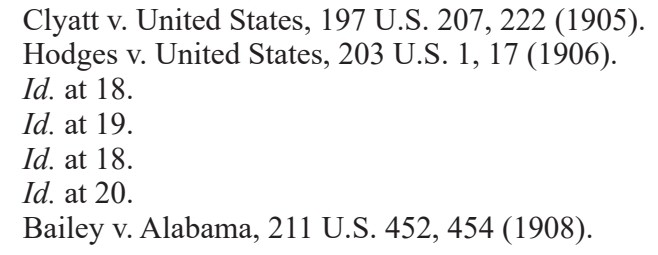


thought that there was no reason to reach the question of the presumption's validity because "it may be that the prosecution will not rely on the statutory presumption but will exhibit satisfactory proof of a fraudulent scheme." ${ }^{87}$ Even "if that evidence was insufficient," he continued, "it hardly will be contended that this Court should require the state courts to release all persons held for trial, where in its opinion the evidence fails to show probable cause." 88 The two provisions, in any event, were separable. "The trouble with the whole case is that it is brought here prematurely by an attempt to take a short cut," ${ }^{89}$ and to free Bailey in advance of the trial.

Bailey was subsequently tried, convicted, and sentenced to 136 days of imprisonment at hard labor. Following Holmes' implicit instruction to bring his action after his conviction, Bailey then appealed the conviction, by which time the Supreme Court had somewhat changed in personnel. Both he and the U.S. attorney general in his brief emphasized that peonage laws were almost entirely targeted at Southern black farm laborers.

The second Bailey opinion written by Justice Hughes, newly appointed and the son of an abolitionist Baptist minister, noted that peonage targeted "the poor and the ignorant, ${ }^{, 90}$ but insisted that the case had nothing whatever to do with race. "We at once dismiss from consideration the fact that the plaintiff in error is a black man. ... No question of a sectional character is presented." ${ }^{91}$ Hughes also conceded that Alabama could punish for mere intent to defraud. However, the only evidence of the intent was Bailey's breach of contract, which created a prima facie evidence of fraud; in effect, Bailey was punished for the presumption of breach of contract. "The contract exposes the debtor to liability for the loss due to the breach, but not to enforced labor." ${ }^{92}$ By requiring labor, which amounted to involuntary servitude, the law violated the Thirteenth Amendment.

Holmes, dissenting, agreed that the fact that it was an Alabama case concerning blacks "does not matter." 93 The law did not punish breach, he maintained, but only fraud, and the presumption that breach meant fraud could be disregarded by jurors with "experience as men of the world," 94 if the evidence warranted it. As for criminalizing the punishment, he wrote, "it does not strike me as an objection to a law that it is effective. If the contract is one that ought not to be made, prohibit it. But if it is a perfectly fair and proper contract, I can see no reason why the state should not throw its weight on the side of performance." "Breach of a legal contract without excuse," he declared, "is wrong." 96

United States v. Reynolds (1914) concerned Ed Rivers, a black man convicted in Alabama of petit larceny. Unable to pay the fine, he agreed to work for J.A. Reynolds, who paid the fine, for nearly ten months to pay off the debt. After about a month, Rivers quit, was convicted of breach of contract, and contracted with

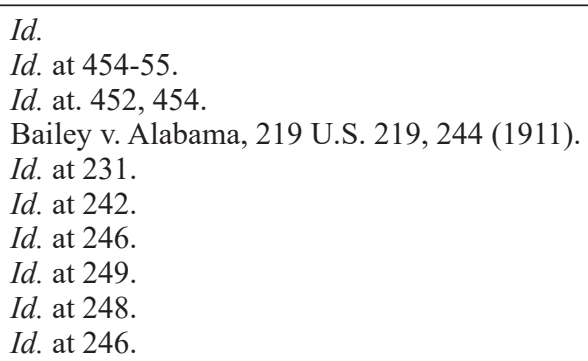


another white man to work off the resulting debt over fourteen months. Rivers then fled and was sentenced to one year on a chain gang. The Alabama criminal surety law permitting enforcement by imprisonment was challenged as violating Congress' ban on criminal surety peonage.

Justice Day, striking down the Alabama law, emphasized that the debt was owed to the surety, not the state, which merely enforced it, and thus the case was a classic instance of peonage, which Congress could prohibit. Criminalizing debt assumed that the obligation to pay was a duty owed the public, as well as the private creditor, but traditionally, debt was considered a private obligation, and thus not to be criminalized. Day's focus was on repeat offenders, like Rivers, who were "kept chained to an ever-turning wheel of servitude. ${ }^{~}{ }^{97}$ No mention was made of race.

Holmes, concurring, characterized the victims of peonage as "impulsive people with little intelligence or foresight, ${ }^{\prime 98}$ whose moral defects would lead them repeatedly to breaches of contract.

In these cases, Holmes is indifferent if not hostile to the incontrovertible fact that peonage laws were a tool for keeping Southern blacks in bondage. In The Common Law, he had written that the only remedy for breach of contract was payment of damages, not "labor for another," ${ }^{99}$ but he seems to have forgotten his own lesson. In Hodges, he does not seem troubled by Brewer's preposterous assertion that American slavery was not race based. Harlan, in his concurrence in Clyatt, had written that the case disclosed "barbarities of the worst kind against these negroes," 100 and the government's brief had asserted that "upon the decision in this case hangs the liberty of thousands of persons, mostly colored, it is true, who are now being held in a condition of involuntary servitude, in many cases worse than slavery itself." ${ }^{101}$ Later, in 1908, assistant attorney general Charles W. Russell produced a well publicized Report on Peonage that followed his journey in the South. He concluded that the "chief support of peonage is the peculiar system of state laws prevailing in the South." 102 Yet with the lone exception of Harlan's concurrence, none of the Court's opinions alluded to race. Holmes' indifference was shared with his colleagues.

Similarly, in Bailey I, Holmes' callousness was revealed in three remarkable comments. In one, he advocated prosecution under a statute of dubious constitutionality because another provision of the law might permit sufficient evidence of guilt. But if the two provisions were separable, as he maintained, why not consider invalidating the dubious provision, in order to forestall the jury from convicting the defendant for the wrong reason? What was there to lose? This is surely judicial restraint taken to an absurd limit.

In the second comment, Holmes thought it self-evident that the state should be able to hold persons for trial in the absence of probable cause, as if white Alabama juries would be likely to disregard a presumption of fraud attaching to black laborers.

United States v. Reynolds, 235 U.S. 133, 146 (1914).

Id. at 150 .

99 Oliver Wendell Holmes, The Common Law 235-36 (1881). Though there are societal implications if debts are not repaid, Holmes did not conclude that this justified criminalizing the failure.

100 Clyatt v. United States, 197 U.S. 207, 223 (1905).

101 Id. at Brief for respondent 3.

102 Charles W. Russell, Report on Peonage 7 (GPO 1908). 
Indeed, there is something odd about a Boston Brahmin referring to white Alabama farmers as "men of the world," as if, untouched by prejudice, they had only recently returned from a grand tour of fin de siècle Europe. Finally, in Reynolds, Holmes simply asserts that blacks caught in peonage are ensnared in problems of their own making. No reference is made to their subjugation or exclusion from the criminal justice system that convicted them. From one famous for advocating the separation of law from morality ${ }^{103}$ comes a moralistic condemnation of the peons, but none for the blatantly racist operation of the law.

\section{SEGREGATED EDUCATION}

Berea College v. Kentucky (1908) concerned a Kentucky law that made it unlawful for "any person, corporation, or association of persons" to enroll white and black students. ${ }^{104}$ Berea College, founded in 1855 by an abolitionist, admitted white and black students, ${ }^{105}$ and the law "was obviously directed at Berea College." 106 The college was found guilty, and fined $\$ 1,000$, a substantial sum for a college that charged no tuition.

Speaking for a seven-two majority, Justice Brewer rested his opinion on the college's corporate charter. Kentucky's constitution empowered the state to amend corporate charters, so long as the original purpose of the charter was not defeated or substantially impaired. As Berea's existing charter, very general and brief, failed to refer to integrated education, the college could not claim that barring integration posed a fatal conflict. Neither party had argued charter revision in its briefs. ${ }^{107}$ Harlan, dissenting, took for granted that integration was a harmless purpose, although the legislature, fearing race mixing and miscegenation, clearly took the opposite position.

Holmes registered a concurrence without an opinion.

Gong Lum v. Rice (1927) concerned a nine year old Chinese-American girl in Mississippi, who was assigned to a black segregated school and claimed that she belonged in a white school. The Mississippi constitution provided for separate schools "for children of the white and colored races," and her family read "colored" to mean "black," while they insisted she was "pure Chinese."108 The Mississippi supreme court, however, interpreted "colored" to mean all races, apart from "pure whites." ${ }^{109}$ On appeal to the United States Supreme Court, Gong Lum argued that as segregation was intended to protect whites from blacks, Chinese deserved "just

103 Oliver Wendell Holmes, Jr., The Path of the Law, 10 HaRv. L. Rev. 457, 459 (1897).

104 Ky. Acts 1904, §1.

105 Paul David Nelson, Experiment in Interracial Education at Berea College, 1858-1908, 59 J. South. Hist. 13 (1974). Berea's "golden age of interracial education" began to be reversed in 1892, when a new president favoring growing white student representation took control. Id. at 17-27.

106 Richard A. Heckman \& Betty J. Hall, Berea College and the Day Law, 66 Reg. OF THE Ky. His. Soc. 35 (1968).

107 The law was amended in 1950 to permit the admission of "qualified negroes." Louisville Courier-Journal, Apr. 15, 1950.

108 Gong Lum v. Rice, 275 U.S. 78, 81 (1927).

109 Id. at 82. 
the same" 110 protection, too. In failing to provide it, "The white race creates itself a privilege that it denies to other races; exposes the children of other races to risks and dangers to which it would not expose its own children. This is discrimination." 111 Accepting both racial segregation and white supremacy, Gong Lum argued that Mississippi denied her equal protection.

Chief Justice Taft, speaking for a unanimous Court, citing a dozen state cases and two federal district court cases, said that the validity of segregated schools had been decided "many times." 112 He concluded that "The decision is within the discretion of the state in regulating its public schools, and does not conflict with the Fourteenth Amendment." 113 Segregation was a closed issue not open for debate.

Holmes' record on educational segregation is passive. In Berea College, the "transparent and undisguised evasion" 114 approved a state's mandating segregation even when individuals coming together under the auspices of a private institution oppose it, but the Court's odd reliance on corporate charters saved it from making constitutional law on the question. Holmes registered a concurrence without an opinion. Was he put off by the evasive charter rationale? Would he have preferred constitutionalizing the segregation of private institutions? Was he willing to defer to the legislature in the absence of a clear mistake? It is impossible to say.

As to Gong Lum, Taft treated segregation as a policy that had been approved so often that its validity could be taken for granted. Hence, the Court could focus only on the anomaly of a Chinese girl, who did not fit a traditional white/black classification. Holmes apparently accepted this reasoning, declining to challenge the Court's assumptions that the black school was substantially equal to the white and that segregation itself was a reasonable goal of public policy. Perhaps because the case seemed to invite only perfunctory attention, Holmes also failed to point out that none of the cases cited by Taft dealt with the state's policy of assigning students, though this was the heart of Gong Lum's contention.

\section{TRANSPORTATION SEGREGATION}

Chiles v. Chesapeake \& Ohio Railway Co. (1910) involved J. Alexander Chiles, a black man who purchased a first class passenger ticket on a Chesapeake train from Washington D.C. to Lexington, Kentucky. He changed trains at Ashland, Kentucky, and took a seat in a car reserved for whites; under protest, he was moved by police to a car reserved by Chesapeake for blacks. He claimed that as an interstate traveler, his rights were abridged by Chesapeake's regulation.

The Court, by a vote of eight to one, found for the railroad. Justice McKenna observed that "the interstate commerce clause does not constrain the actions of carriers. But on the contrary leaves them free to adopt rules and regulations for the government of their business." The rules must be reasonable, of course, but that

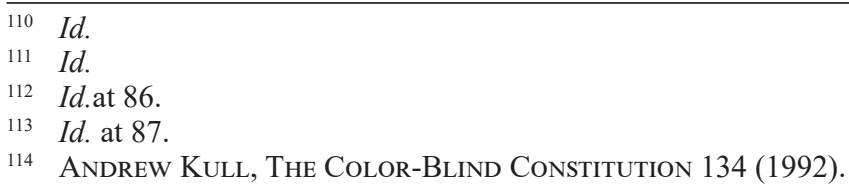


is no problem in this case. ${ }^{115}$ Plessy v. Ferguson was cited as precedent. ${ }^{116}$ Harlan dissented without an opinion.

Butts v. Merchants and Miners Transportation Co. (1913) concerned Mary Butts, a black woman who purchased a first class ticket on a boat from Boston to Norfolk, but was forced to take second class accommodations with other blacks. She claimed this policy infringed her right to be free of discrimination in public accommodations under the Civil Rights Act of $1875 .{ }^{117}$ To the extent that the act applied to conditions within states, it had been declared unconstitutional in the Civil Rights Cases (1883), ${ }^{118}$ but Butts argued that the act remained valid when applied to navigable waters and federal territories.

The Supreme Court unanimously rejected her contention, Justice Van Devanter observing that the "manifest purpose [of the Civil Rights Act] was to enact a law which would have a uniform operation wherever the jurisdiction of the United States extended." 119 Congress would never have adopted a law that applied only in these narrow conditions. It "is not possible to separate that which is constitutional from that which is not," 120 and so with the remainder of the act declared unconstitutional, her argument failed.

McCabe v. Atchison, Topeka \& Santa Fe Railway Co. (1914) produced a highly unusual opinion. Oklahoma had passed the Separate Coach Law that required separate but equal facilities on railway cars for whites and blacks. ${ }^{121}$ The railway, asserting that there was insufficient demand for black dining and sleeping cars, refused to provide them. Justice Hughes, speaking for a unanimous Court, dismissed the railway's claim. "It makes the constitutional right to depend upon the number of persons who may be discriminated against, whereas the essence of the constitutional right is that it is a personal one." 122 Thus, the question was not whether the policy treated blacks, as a race, equitably, but the much tougher matter as to whether it treated blacks, as individuals, equitably. The policy likely would have passed the first test, but clearly not the second. Though Hughes never questioned the lawfulness of segregation, he plainly believed that there was something noxious about racial classifications. Otherwise, presumably, he would have no reason to question a policy that on purely economic grounds would have seemed entirely reasonable.

However, as none of the complainants ever traveled on the railway, they lacked standing and the suit was dismissed. Had the question of standing been addressed at the outset, where normally such questions are resolved, Hughes' insistence on the railway's meeting its separate but equal obligation would never had been written. But as the circuit court had addressed the merits, finding that "quality of service . . does not require permanent provision of service, irrespective of the demand for it," 123 Hughes had an excuse to confront the merits, and it seems that he

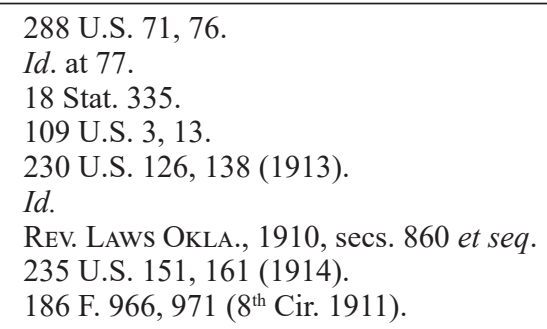


embraced the excuse with enthusiasm. By addressing standing at the conclusion of his opinion, he made the dicta prominent, and indicated a future path for the Court. In looking at the decades long process of destroying separate but equal, this case, which for the first time took "separate but equal" seriously, deserves pride of place as the initial judicial attack on Jim Crow, and is an excellent example of Hughes' political sagacity at work.

Holmes joined three Southern Justices (White, Lamar, and McReynolds) in concurring without an opinion.

South Kensington \& Cincinnati Street Railway Co. v. Kentucky (1920) concerned a single trolley that travelled five miles from Kentucky to Ohio, charging five cents for the trip. Kentucky required that the white and black races be separated by a "good and substantial wooden partition," 124 while Ohio banned segregation in trolleys. The trolley company was indicted in Kentucky for violating its segregation law, but complained that the Kentucky law was an invalid interference with interstate commerce.

Justice McKenna, speaking for a six-three majority, held that the "regulation of the act affects interstate business incidentally and does not subject it to unreasonable demands." 125 The railway was chartered in Kentucky, and therefore the law regulates the charter and "is not a regulation of interstate commerce." 126 Finally, McKenna emphasized the "necessity, under our system of government, to preserve the power of the states." 127

In $M c C a b e$, we do not have access to Holmes' unpublished concurrence, but we do have Hughes' reply indicating that Holmes agreed with the dismissal, but not the separate but equal dicta. Hughes concluded that Holmes' reading of the equal protection clause did not rule out racial discrimination. He wrote Holmes that the law compelled "a black man [to] sit-up all night - just because he is black, unless there are enough blacks to make a 'black sleeping car' pay. I don't see that it is a case calling for 'logical exactness' in enforcing equal rights, but rather as it seems to me it is a bald, wholly unjustified discrimination against a passenger solely on account of race." $" 128$

In McCabe, Holmes had apparently used "logical exactness" to minimize the discrepancy between the treatment of white and black passengers, but as the railway did not offer black passengers roughly the same accommodations, arguments on equality could hardly be dismissed as logic-chopping; it offered them no accommodations at all. The implication is that Holmes agreed that the suit should be dismissed, and on the merits shared the view of the three Southern justices.

As to Chiles and South Kensington, Holmes silently agreed with the majority. He had often interpreted the commerce clause broadly. In Swift \& Co. v. United

\footnotetext{
252 U.S. 399.

Id. at 404.

$I d$. at 403 .

Id. at 404 .

128 Letter from Holmes to Hughes, (Nov. 29, 1914), in Alexander M. Bickel \& Benno C. Schmidt, 9 History of the Supreme Court of the United States: The Judiciary AND ReSPONSIBLE Government, 1910-1921, at 780 (1984). A few years earlier, Hughes, speaking on behalf of Tuskegee Institute had declared, "We cannot maintain our democratic ideals as to one set of our people and ignore them as to others." MerLo Pusey, Charles Evans Hughes 216 (1951).
} 
States (1905), for example, he emphasized that interstate commerce "is not a technical conception, but a practical one, drawn from the course of business." 129 In this regard, Justice Day, dissenting in the trolley case, pointed out that in an earlier case involving the same railway, a local Kentucky law that regulated the number of cars and passengers was struck down as an unconstitutional intrusion into interstate commerce. Day thought that the burden imposed on the railway by segregation was substantial, with the few passengers (and even fewer blacks) served rendering the changes required impractical. Holmes apparently did not agree on the burdensome nature of segregation. Nor did he see a problem in Chiles.

\section{RESIDENTIAL SEGREGATION}

Prior to 1910, there had been little migration of Southern blacks to border or Northern cities, but drawn by a labor shortage that generated higher wages, black migration at this point began to change. ${ }^{130}$ Activated by white economic and social fears, a number of cities, including Louisville, adopted ordinances that barred whites and blacks from occupying houses on blocks where the majority was of a different race. Charles Buchanan, a white real estate agent, and William Warley, a black home buyer, signed an agreement to purchase a house on a majority white block. Warley declined to complete the purchase when he learned that the ordinance would prevent him from occupying the house, complaining that the law negated specific performance of a real estate contract he had signed. Louisville countered that the law was intended "to prevent conflict and hostility between the white and colored races ... and to preserve the public peace and promote the general welfare."'131

Justice Day, speaking for a unanimous Court, conceded that "there exists a serious and difficult problem [of] race hostility," ${ }^{132}$ but concluded that the ordinance deprives buyer and seller of their due process property rights..$^{133}$ The law may have been directed only at occupancy, but its connection to buying and selling was obvious. Nor could the law be justified by the goal of racial purity, for it permitted widespread interracial contact. ${ }^{134}$ Nor could it be justified in terms of maintaining whites' property values, as undesirable whites were not prevented from moving to the block. ${ }^{135}$ Day distinguished the case from Plessy, where blacks had no property interest in where they sat, which merely reflected social equality, a topic he believed the equal protection clause avoided, ${ }^{136}$ though he implicitly agreed that "prohibiting the amalgamation of the races" was a legitimate public policy decision. ${ }^{137}$ This was the first decision that found

196 U.S. 375, 378.

130 William J. Collins \& Marianne H. Wanamaker, The Great Migration of Black and White: New Evidence on the Selection and Sorting of Southern Migrants, 75 J. Eco. HisT. 947 (2015).

131 The brief also referred to preserving "racial integrity," and to "negroes carry[ing] a blight with them wherever they go." Brief for Defendant in Error 11, 13 (1917).

132245 U.S. 60, 80.

133 Id. at 82.

134 Id. at 81.

${ }_{135} I d$. at 82

136 Id. at 79.

137 Id. at 81. 
segregation unconstitutional, and was greeted as a great victory for civil rights. ${ }^{138}$ Holmes wrote a dissent, but failing to get another justice to join him, decided not to make it public. ${ }^{139}$ Holmes objected that the case was likely "manufactured," and thus should not have been heard. In this, he was clearly correct, for both parties colluded to have the law struck down. He also complained that Buchanan's suit was brought on behalf of Warley, which was improper. As in McCabe, Holmes declined to join a majority making a larger policy point, when well established technical concerns dictated that the case should never have been heard.

Corrigan v. Buckley (1926) concerned the practice of racial restrictive covenants, that is, private agreements not to sell or rent real property to certain designated groups, typically blacks but also sometimes Jews, Mexicans, Chinese, Armenians, Japanese, Persians, Syrians, American Indians, and others. ${ }^{140}$ The practice first appeared in the South in 1904, and spurred on by the Great Migration sparked by World War I and subsequent race riots, it appeared in the North by 1922 , and rapidly became nationalized. ${ }^{141}$ As a practical matter, the key question was whether courts could enforce such agreements. In Title Guarantee \& Trust Co. v. Garrott (1919), a California court found no violation of the Fourteenth Amendment because the judiciary "sanctions discriminations that are the outgrowths of contracts made by individuals." 142

The Supreme Court heard Corrigan, where a suit in equity was brought to enjoin conveyance of real estate in Washington, D.C. in violation of a racial restrictive covenant. Irene Corrigan, a white homeowner, had agreed to a covenant but later had also agreed to sell her property to John Buckley, a black man, claiming that judicial enforcement of the covenant deprived her of Fifth, Thirteenth, and Fourteenth Amendment rights. Justice Sanford, speaking for a unanimous Court, disposed of the suit in fewer than five pages. The amendments she cited, he pointed out, all targeted only governmental action, while the covenant constituted private action. Thus, "in the absence of any substantial constitutional or statutory question giving us jurisdiction," he concluded, "we cannot determine upon the merits of the contentions." 143 Though Sanford, therefore, refused to decide the case on its merits, in dicta he noted that "it is obvious, upon their face, that [the amendments] do not in any manner prohibit or invalidate contracts entered into by private individuals in respect to the control of their property." "144 Confusing the dicta for the ratio, a number of state courts relied on Corrigan in upholding the judicial enforceability of covenants. ${ }^{145}$

138 William B. Hixon, JR., Moorfield Storey and the Abolitionist Tradition 142 (1972); William H. Baldwin, Jr., Unconstitutional Segregation, New Republic, Jan. 19, $1918,345$.

139 The opinion may be found at Josh Blackman's Blog, July 18, 2017.

140 U.S. DeP't of Justice, Prejudice And Property 18 (1948).

141 Michael Jones Corea, The Origins and Diffusion of Racial Restrictive Covenants, 115 PoL. SCI. Q. 541, 550 (2001).

142 Title Guarantee v. Garrott, 42 Cal. App. 152, 183 (1919).

143271 U.S. 323, 332.

144 Id. at 331.

145 E.g., United Cooperative Reality Co. v. Hawkins, 269 Ky. 563, 565 (1937); Ridgeway v. Cockburn, 296 N.Y. 936, 942 (1937); Meade v. Dennistone, 173 Md. 295, 302 (1938); Doherty v. Rice, 240 Wis. 389, 397 (1942); Lyons v. Waller, 191 Okla. 567, 569 (1942). 


\section{JURY EXCLUSION}

Two nineteenth century cases might have provided powerful precedents for later jury exclusion cases. First, in Strauder v. West Virginia (1880), the Supreme Court held that a state law banning blacks from juries denied them equal protection of the laws. As Justice Strong wrote, the law excluding them "is practically a brand upon them, affixed by law; an assertion of their inferiority, and a stimulant to the race prejudice which is an impediment to securing to individuals of the race that equal justice which the law aims to secure to all others." 146 Second, in Yick Wo v. Hopkins (1886), the Supreme Court accepted overwhelming data of disparate racial impact as sufficient to establish unconstitutional administration of an otherwise valid law that was not discriminatory on its face ${ }^{147}$ No evidence of discriminatory intent was required.

Brownfield v. South Carolina $(1903)^{148}$ was the occasion of Holmes' first civil rights opinion. John Brownfield, a black barber, was convicted of murder and sentenced to be hanged. Brownfield had refused to pay a $\$ 3.10$ poll tax; although this was a civil and not a criminal offense, a court officer had pulled his gun and attempted to arrest him; in the scuffle, the officer had been killed. Brownfield filed a pretrial motion to quash the indictment on the ground that blacks had been unlawfully excluded from the grand jury (four-fifths of the county were black), and offered to present corroborating evidence. A judge ruled against the motion, and an oral challenge was also denied. The judge also denied a motion alleging black exclusion from the petit jury, remarking that as he "was not personally acquainted with the jurors selected, I could not assume the facts to be as alleged," even though he had supervised the voir dire. A judge on the South Carolina Supreme Court (and a brother of the trial judge) found no grounds for discrimination because Brownfield was not entitled to be tried by a jury containing blacks and because the state constitution and statutes did not discriminate. He failed to mention the petit jury. ${ }^{149}$ Brownfield complained to the United States Supreme Court that blacks had been excluded from his grand and petit juries on account of race in violation of the equal protection clause.

Holmes, relying on the South Carolina Supreme Court ruling, held in a brief opinion that the allegations were controverted, but the evidence submitted by Brownfield was not agreed to by the judge. ${ }^{150}$ In the absence of proven allegations, the Court affirmed the lower court's ruling.

Rogers v. Alabama (1904) involved a black man convicted of murder, who complained that though a majority of the population in his county was black, none was selected for his grand jury as a result of their deliberate exclusion by officials. The Alabama supreme court denied his appeal on the ground that his motion was "unnecessarily prolix," as provided in the state civil code.

Holmes, speaking for a unanimous Court, wrote that the motion asserting a

146100 U.S. 303, 308. In Carter v. Texas, 177 U.S. 442, 449 (1900), the Court held that black defendants must be granted an opportunity to establish jury exclusion.

147118 U.S. 356.

148 This case is thoroughly discussed in Thomas J. Rubillo, Trial and Error: The CaSe of John Brownfield and Race Relations in Georgetown, South Carolina (2005).

149 State v. Brownfield, 39 S.E. 2 (S.C. 1901).

150 Brownfield v. South Carolina, 189 U.S. 426, 428. 
"constitutional right . . . cannot be withdrawn for prolixity . . . under the color of local practice." ${ }^{151}$ Rogers raised a federal question. The judgment was reversed, and the case remanded.

Rawlins v. Georgia (1906) concerned a black man convicted in Florida of murder, who complained that blacks were excluded from his jury in violation of the Fourteenth Amendment.

Justice Brewer, speaking for a unanimous Court, denied the appeal, writing that "actual discrimination . . . must be proved or admitted," 152 but all that was offered was an "affidavit of the defendants ... stating that the facts set up in the motion were true" to their best knowledge, information and belief. ${ }^{153}$ As with Brownfield, this was insufficient.

Martin v. Texas (1906) concerned Rufus Martin, a black defendant, who was convicted of murdering a white farmer. Martin maintained that he was a victim of jury discrimination; a quarter of the potential jurors were black, but they were all excluded to guarantee a white jury. Texas responded that only 150 blacks were qualified, in contrast to 12,000 whites, and denied that it had engaged in discrimination.

In a brief opinion, Justice Harlan, speaking for a unanimous Court, ruled for Texas, citing the "absence of such proof [required for] overcoming the denial on the part of the state." ${ }^{154}$ As with Brownfield and Rawlins, he said there was no evidence to support the charge. Otherwise discrimination could be established simply by the absence of blacks on juries. ${ }^{155}$

Thomas v. Texas (1909) concerned Marcellus Thomas, a black defendant, who was convicted of murdering a white man. The defendant pointed to a quarter of the jury pool being black, attributing their total exclusion to discrimination.

Chief Justice Fuller, in a brief opinion for a unanimous Court, observed that Thomas had raised a question of fact, and that "the ordinary rule is that questions of fact will not be reviewed by this Court on writs of error to state courts." $156 \mathrm{He}$ conceded that the Court might intervene, when "these decisions constitute such abuse as amounted to an infraction of the federal Constitution, which cannot be presumed, and which there is no reason to hold on the record before us." ${ }^{157} \mathrm{He}$ pointed out that the grand jury contained a black juror and that "there were negroes on the venire from which the jury which tried the case was drawn, although it happened that none of them were drawn out of the jury box." 158

Franklin v. South Carolina (1910), a high profile case that saw the NAACP raise issues of criminal peonage laws and self-defense, ${ }^{159}$ concerned Pink Franklin, a black farmer convicted of murdering a white constable, who had come to arrest him for a peonage violation. Despite a sizable black population, none had been

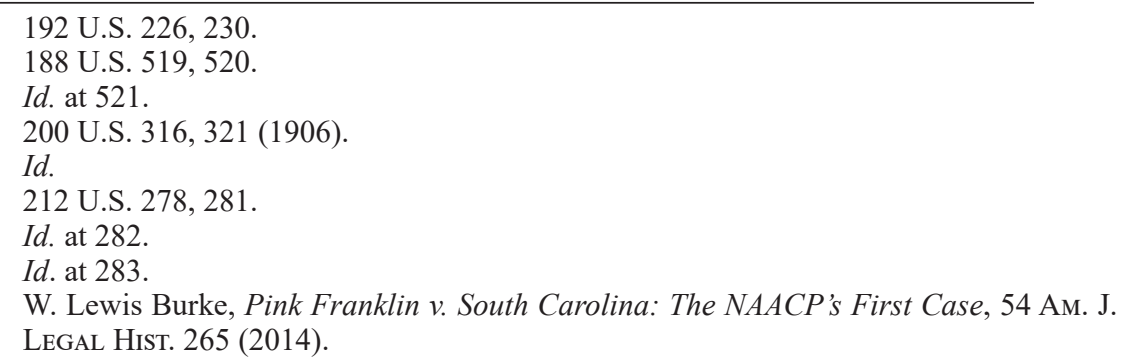


chosen for the grand or petit juries. The South Carolina supreme court upheld the conviction, noting that nothing in the laws relevant to jury selection mentioned race.

Speaking through Justice Day, the Supreme Court again insisted on proof that officials in charge of jury selection intended to exclude blacks, and upheld the conviction. ${ }^{160}$

Brownfield, Rawlins, Martin, Thomas, and Franklin all saw claims of black jury exclusion denied for want of evidence of discriminatory intent. Insisting on intent is perfectly reasonable in ordinary criminal cases. However, insisting on intent in these civil suits is jarring for three reasons. First, it placed a heavy burden on the plaintiffs because it is much easier for the state to disguise discriminatory intent than effect, and the plaintiff for financial and other reasons is much less able to assume heavy burdens. Second, insisting on intent failed to incentivize states to remedy the exclusion of blacks; indeed, burdening plaintiffs actually incentivized states to continue the practice. The contrast with Yick Wo is instructive. There, the Court looked past a facially race neutral law to its biased application, ruling that this application, without reference to evidence of intent, was sufficient to demonstrate discrimination. In the jury exclusion cases, it refused to apply this reasoning, though the subject matter - jury selection versus licensing of laundries - would clearly seem to dictate otherwise, for jury selection may involve loss of liberty or death. Third, while courts may understandably be reluctant to reverse practices beyond their purview, jury selection goes to the heart of the criminal justice system, and is very much their business. The Court's deference thus becomes even harder to justify. The Court might have ruled, for example, that when black exclusion from juries is statistically obvious, a presumption of discriminatory intent would be created, shifting the burden of proof from the plaintiffs to the state and according with simple common sense; if the state were unable to rebut the presumption, unlawful exclusion would be established. ${ }^{161}$

Holmes' contribution to jury selection jurisprudence was modest. He wrote only the Brownfield and Rogers opinions and silently agreed in the four other cases. In Rogers, he found for the plaintiff, whose appeal had been denied by the Alabama supreme court on the bizarre ground that it was "unnecessarily prolix"; perhaps, had Alabama relied on the absence of discriminatory intent, it might have prevailed. Apart from this case, Holmes was evidently willing to avert his eyes from the overwhelming arithmetic evidence of discrimination that blanketed the five other cases.

\section{LYNCHING}

Riggins v. United States (1905) concerned Riggins, a white man in Alabama, who was indicted for lynching Maples, a black man accused of murder, because he "was of African descent," 162 in violation of federal law. Riggins sought a writ of habeas corpus that would release him on the ground that no federal law applied to the lynching.

160218 U.S. $161,167$.

161 The Court adopted this rationale concerning employment discrimination. Griggs v. Duke Power Co., 401 U.S. 424 (1971).

162194 U.S. 547, 548. 
Chief Justice Fuller, in a brief opinion for a unanimous Court, quashed the writ on the ground that Riggins had asked the Court "to decide questions in advance of final adjudication, contrary to the settled rule." 163

United States v. Shipp (1909) began when a black carpenter in Tennessee, Ed Johnson, was convicted by an all-white jury of raping a white woman, and sought a writ of habeas corpus on the ground that blacks had been excluded from the jury and a change of venue request denied. The Court issued a stay of execution, and ordered him detained in Sheriff Joseph Shipp's county jail. However, Johnson was lynched by a white mob with the connivance of Shipp. Shipp denied his guilt, and asserted that his sworn denial should be conclusive; if it were false, said, he could be prosecuted for perjury. He also challenged the Court's jurisdiction, noting that as sheriff he was not a federal officer.

In an opinion for a unanimous Court, Holmes announced that it was absurd to imagine that "a general denial and affidavit should dispose of the case." 164 Holmes added that Johnson had been detained "to abide the further order of this Court,"165 and so the sheriff, though a county employee, was acting as a federal officer. The Court, therefore, had jurisdiction to hear this case and to try Shipp for contempt of court. Holmes was clearly outraged that Shipp had characterized the opposing arguments as "frivolous."

In the contempt trial, the only criminal case ever tried before the Supreme Court, Chief Justice Fuller in an unusually long and detailed opinion concluded for a five-three Court that "Shipp not only made the work of the mob easy, but in effect aided and abetted." 166 Shipp was held in contempt.

Though lynching was commonplace during this period, its cruelty, bigotry, and denial of the rule of law all suggest that the Court would find it uniquely abhorrent. Holmes, as a young man, had described it as almost an irresistible force that "listens to no argument, for it is very little more than a mere animal movement. One might as well reason with a she-bear from whom he had stolen her cubs."167 The opinions in both Shipp cases acknowledged its horror. But in Riggins, where the Justice Department, influenced by President Theodore Roosevelt's outrage at lynching, brought the prosecution, Fuller's opinion made no mention of lynching. As for sheriff Shipp, he was sentenced to ninety days in a federal jail. Upon his release, he returned home and was met by a crowd of ten thousand of his fellow citizens serenading him with Dixie.

\section{Miscellaneous}

A pair of cases involving race produced unanimous opinions with which Holmes silently joined. New York ex rel. Bryant v. Zimmerman (1928) $)^{168}$ concerned a challenge to a state law requiring oath bound organizations of twenty or more

\footnotetext{
199 U.S. $547,551$.

203 U.S. 563, 574.

Id. at 575 .

166 In dissent, Justice Peckham, while abhorring the lynching, found no evidence that the sheriff had been responsible. 214 U.S. 386, 426.

167 Oliver Wendell Holmes, Jr., Crime and Automatism, 35 Atlantic 466 (Apr., 1875).

168278 U.S. 63.
} 
members to file their constitutions, oaths, and membership lists with the state. Zimmerman, a member of the $\mathrm{Ku}$ Klux Klan, claimed that this abridged his due process right to freedom of association. Justice Van Devanter held that given the Klan's notoriety, the requirement was reasonable.

Ancient Egyptian Arabic Order of Nobles of the Mystic Shrine v. Michaux (1929) ${ }^{169}$ involved two Shriner organizations, one for white members and the other for black. The white order sought an injunction preventing the black order from using its name, constitution, emblems, and regalia. The black order rejected the claim that the white order had exclusive use of these, and pointed to its own incorporation under an act of Congress. Van Devanter found no evidence of fraud on the part of the black order, and denied the request for injunctive relief.

\section{Conclusions}

It is easy from the moral perch of 2020 to condemn Holmes' record on race compiled a century or more ago. In its general indifference to the claims of African Americans, it is inarguably appalling. One might answer that in in those times, whites, North and South, were for the most part indifferent to these claims. One might add that under the Fuller Court (1888-1910), every civil rights case except those involving lynching was decided against blacks, typically on technical grounds, with no reference to the overarching fact of violence, terrorism, and discrimination to which this sizable portion of the population was subject. One might also point to the prevailing judicial rhetoric of rights that tended to favor the interests of the strong against the weak. ${ }^{170}$ There is no evidence that the Court ever considered taking judicial notice of the devastating consequences of Jim Crow that were present for all to see. In short, it might be said in Holmes' defense that he was simply a man of his time, and that his actions (or inactions) reflected this fact.

Except that Holmes was not simply a man of his time. Edmund Wilson pointed to Holmes' "unshakable self-confidence, his carapace of impenetrable indifference to current pressures and public opinion, [his] Brahmanism, his highminded egotism, and his philosophical temper of mind [that] equipped him with impenetrable integument." 171 Holmes, a proud iconoclast, delighted in swimming against the flow. A man of his time, for example, might have approved a crabbed commerce clause ${ }^{172}$ or liberty of contract. ${ }^{173} \mathrm{He}$ did not. Or he might have approved national security rationales for suppressing speech. After an irresolute beginning, ${ }^{174}$ he did not. ${ }^{175}$ Indeed, in one of these cases, a delegation of three justices, joined by his wife, urged him to withdraw his stinging dissent in support of the speech rights

\footnotetext{
279 U.S. 737.

170 E.g., Lochner v. New York, 198 U.S. 45 (1905); Hammer v. Dagenhart, 247 U.S. 251 (1918).

171 WiLSON, supra note 28, at 782, 794-95.

172 Hammer, supra note 170, at 277.

173 Lochner, supra note 170, at 74.

174 Schenck v. United States, 249 U.S. 47 (1919);; Frohwerk v. United States, 249 U.S. 204 (1919); Debs v. United States, 249 U.S. 211 (1919).

175 Abrams v. United States, 250 U.S. 616, 624 (1919); Gitlow v. New York, 268 U.S. 652, 672 (1925).
} 
of Russian Jewish communists. He paid no attention to them. ${ }^{176}$ While Holmes appears to have been influenced by several young Progressives and their so-called House of Truth, ${ }^{177}$ he was emphatically not a cypher blown by prevailing winds. $\mathrm{He}$ was stubbornly, if always politely, his own man.

It is difficult, then, to avoid the conclusion that Holmes was genuinely indifferent to the plight of blacks, particularly in the South, though for most of the year he lived in the Southern city of Washington and would have observed their discrimination daily. It was plain that each of the black litigants in the cases he heard were proxies for hundreds or even thousands, who for financial or other reasons were unable to make their pleas known. There is no sign that this troubled him. Similarly, though he often wrote about foreseeable harm, ${ }^{178}$ he seemed blind to the obvious and intended consequences of the practices he voted to uphold. In this, he differed radically from his disciple, Frankfurter, whose emotional commitment to policies frequently clashed with his principled commitment to defer to legislatures. Holmes evinced none of Frankfurter's public agonies because he seems to have lacked the policy engagements. ${ }^{179}$ In his voluminous correspondence, which often touched on current events, he almost never mentioned race, and one of the very few reform ideas he embraced was eugenics, which was then marinating in racism. If the status of blacks was not resolved as many of the abolitionists might have hoped, it was with few exceptions evidently resolved enough for him. ${ }^{180}$

Holmes' response to the race question reflected his general view toward life. In this, society was not an organic whole, but merely the sum of individuals, each struggling to advance his own interests. The place of honor went to honor, that is, to the obligation to do one's duty, to fulfill the expectations inhering in one's position, for example, in the soldier's faith "to throw away his life" without hesitation or doubt at the command of his superior. Honor, in this sense, overlaps with authenticity, the obligation to be true to oneself for one's own sake. The ideal, then, would be an autonomous individual guided by rational deliberation, impervious to efforts at manipulation, and adhering to "an order which is inseparably indexed to a personal vision." 181 What of the world around him? Holmes accepted the social order, but in innumerable comments made it clear that he regarded much of it as a façade concealing the ineradicable fact that "we may substitute free struggle for life."182

176 Dean Acheson, Morning and Noon: A Memoir 119 (1965).

177 Brad Snyder, The House of Truth (2017).

178 Oliver Wendell Holmes, Jr., Privilege, Malice and Intent, 8 Harv. L. Rev. 1, 11-12; Elmer v. Fessendan, 151 Mass. 359 (1890); Commonwealth v. Peaselee, 177 Mass. 267 (1901).

179 Thus, while Frankfurter was ever the Court politician seeking to influence the votes of his colleagues, Holmes maintained a courteous aloofness.

180 Wilson remarked that Holmes was "as free as was possible for men of their generation from common nineteenth century prejudices." Supra note 28, at 782. In an era of widespread anti-Semitism, he corresponded with a number of Jewish acolytes-Harold Laski, Felix Frankfurter, Lewis Einstein. Yet what is striking about the letters is an intellectual repartee untouched by personal concerns. At one point, Laski wrote, asking if they might address each other by their first names. Holmes responded with his usual "Dear Laski." On the other hand, this formalism may have simply been habitual: in his often affectionate letters home during the Civil War, Holmes invariably signed them OWH, Jr.

181 Charles Taylor, Sources of the Self: The Making of the Modern Identity 510 (1989).

182 Vegelahn v. Gunter, 167 Mass. 92, 107 (1896). 
In the end, so potent was Holmes' preoccupation with being true to himself that it left little room for caring about others. Had Holmes believed human nature to be essentially cooperative and compassionate, perhaps the self-absorption might have proven more benign. But he dismissed all this as fantasy. It is not surprising, then, that the wounds from the Civil War, physical and emotional, did not sensitize him to the claims of injustice, though they did confirm his belief in evil and pain, not only as metaphysical constructs, but more pressingly, as dominant, supremely important practical facts.

Yet he did not dwell on the past, as Robert Burns wrote, "nursing her wrath to keep it warm." 183 Holmes understood what he had lost-for example, the innocence, optimism, and idealism that had induced him to enlist in the army-was irretrievably gone, and that he could not return to his old self, in fact, that there was something weak and dishonorable about such nostalgic reveries. At the same time, his broad lack of interest in the personal past also meant that forgiveness, either as a practical accommodation or as a Christian virtue, did not concern him much. Indeed, when he contemplated venality (as he often did), it usually took the form of jaunty one-liners, not gloomy introspection, moral outrage or concrete action.

There was perhaps an element of self-flattery in this pose, for it presumed an elevated position far above the madding crowd. There was also perhaps an element of self-protection here, as if the casual indifference had calcified into a shield safeguarding him from the latent consequences of the trauma he had suffered decades earlier. Holmes' rejection of a tempting preoccupation with the past was thus a sign of both practical adaptation and emotional maturity. No wonder he had no use for reformers, who seemed to deny the omnipresent fact of struggle and, as he said as a young man, "believe in the upward and onward-who talk of uplift, who think that something in particular has happened and that the universe is no longer predatory." 184

It is not surprising, then, that his youthful dalliance with abolitionism failed to remind him a half century later of the sorry plight of Southern blacks. Of course, there was the stentorian voice of his colleague, Harlan, to bring it to his attention. But Holmes did not think much of Harlan, writing that he has a mind like a "powerful vise the jaws of which couldn't be got nearer than two inches to each other." 185 His opinions, often full of moral condemnation, seemed to Holmes to parade virtue like a prize bull. "Certitude," he wrote, "is not test of certainty."186 For Holmes, truth merely meant "that I cannot help believing it." 187 Thus, was his ever-present arrogance married to a cosmic humility.

These attitudes informed Holmes' vision of law and politics, as well. "The first requirement of a sound body of law," he wrote in The Common Law, "is that it should correspond with the actual feelings and demands of the community, whether right or wrong." "188 That is, if the law does not reflect these feelings and demands, it may simply be ignored or, worse, general disorder might erupt, producing seriously bad results and undermining the very rule of law. In this, Holmes is very close

183 Robert Burns, Tam O’Shanter and Souter Jenny 4 (1830).

184 Holmes, supra note 17 , at 25.

185 Holmes-POLlOCK, supra note 5, at 2:7-8.

186 Oliver Wendell Holmes, Jr., Collected Legal Papers 311 (1920).

187 Id. at 319.

188 Holmes, supra note 99, at 41. 
to Hobbes' position that a bad ruler must be preferred to no ruler at all because disorder is the ultimate condition to be avoided. Yet the effect of the argument is to present a choice of bad law versus no law, when the real choice is among various laws of various rationales and qualities. For this reason, his stance lends itself to a support of the status quo, almost regardless of how defective the status quo might be.

It also logically leads to the position that courts should declare laws unconstitutional only when they cannot avoid doing so. The law may seem to a judge foolish, unworkable, even immoral, but these are not his proper concerns. These are matters for the lawmakers. The judge should ask only if the law is clearly unconstitutional. If it is not, questions of doubt should be resolved in favor of the lawmakers. For Holmes, for whom duty was of immense importance, this was how judges were obliged to act.

What is most striking is that while we take it for granted that great men seek after power, Holmes seems determined to limit that power. The great monarchsHenry VIII, Peter the Great, Louis XIV - worked ceaselessly to centralize power in their own hands. Great presidents - Lincoln, Franklin Roosevelt - to a much lesser degree did the same. In ordinary speech, we may in fact conflate "great" with "powerful." Holmes plainly does not fit the mold, and the explanation does not lie in self-doubt, a predilection to give in to others, or a temperament of overweening modesty, but rather in his sense of duty. On the issue of race, Holmes exhibited a level of deference that seems almost unthinking in its automatic consistency. His demands on lawmakers are virtually nonexistent. Within the Court, too, his role is largely passive, contributing few opinions and even declining to file lone dissents.

It was not difficult for Holmes to fixate on politics as struggle. As a bright son of intellectual Brahmans, as a wounded warrior in the Civil War, as a pathbreaking scholar in The Common Law, as a renowned judge on the Supreme Judicial Court of Massachusetts and then the United States Supreme Court, he had always seemed to emerge from struggles triumphant. In his eyes, perhaps, these repeated victories underscored the fundamental social fact of struggle and at least the potential worthiness of the victors. His is the unmistakable voice of one who managed to come out on top - as a popular biography put it, as The Yankee from Olympus. ${ }^{189}$

From this perspective, as Judge Posner observed, "The democratic political process was merely the civilized, because non-violent, method of regulating the relative strength of the competing forces in society." 190 Suppose the results favor only the short-term interest of the dominant forces? Suppose the results are indisputably immoral? Suppose the results are anti-democratic? Holmes is not insensible to these possibilities. He never romanticized what he called, as a young man, "the thick fingered clowns we call the people_-vulgar, selfish and base."191 "I look at man through Malthus' glasses — as like flies," he wrote Laski, "here swept away by pestilence - there multiplying unduly and paying for it." ${ }^{192}$ Or as he wrote to Pollock, there is "no reason for attributing to man a significant difference in

189 Catherine Drinker Bowen, Yankee from Olympus (1944). The Magnificent Yankee, a sentimental biography of Holmes, was a popular 1950 movie.

190 Richard A. Posner, Reflections on Judging 156 (2013).

191 Holmes, supra note 17, at 71.

192 HoLMES-LASKI, supra note 7, at 1: 762. 
kind from that which belongs to a baboon or a grain of sand." 193 There is hyperbole here, of course, but there is also a deep skepticism as to the wisdom and virtue of his fellow human beings and no illusion that democracy guaranteed good results.

This was hardly a secret to those who knew him. William James thought Holmes a model of "cold-blooded conscious egotism and conceit." 194 James Bradley Thayer considered him "wanting sadly in the noblest region of human characterselfish, vain, thoughtless of others." ${ }^{195}$ Benjamin Kaplan (who only knew of him) labeled him "a tough old party, quite aware that he was deficient in empathy."196 Beneath his daunting charm and politesse, was Holmes unmistakably something of a cold fish?

Yet notwithstanding his evident disdain for ordinary people, Holmes as a judge was known for his reluctance to overturn laws enacted by the representatives of these ordinary people or even widespread unwritten customs. Time and again, he would insist, in Thayer's words, that he would uphold them unless they constituted "not merely. . . a mistake, but . . . a very clear one - so clear that it is not open to rational question." 197 In case after case, he deferred to the legislature. ${ }^{198}$

"The life of the law," in his mantra, "is not logic; it is experience." $199 \mathrm{He}$ ridiculed those formalists, who imagined law "a brooding omnipresence in the sky, ${ }^{200}$ emphasizing that it is created by real people to serve their purposes. Would Holmes inquire as to what these purposes were? Or was that none of his - and the Court's - business? But if he refused to inquire, how is law for him different from commands from thugs? Of course, lawmakers can point to a legitimate authority that thugs cannot. But do lawmakers retain this authority, even when they behave like thugs, for example, when they undermine their own democratic legitimacy by banning blacks from voting? In his classic Lochner dissent, Holmes spoke of infringements on due process liberty that abridged "fundamental principles as they have been understood by the traditions of our people and our law." 201 Did racial discrimination abridge the "fundamental principle" of equality? Or, because the discriminatory practice had (sadly) been sanctioned "by the traditions of our people and our law," was it therefore permissible? Faced with this dilemma, what was Holmes to do? He did not worship the past. He thought it "revolting to have no better reason for a rule of law than that it was laid down in the time of Henry IV." 202 Yet in general, he respected precedents, which, indeed, comprised the subject matter of the book that first made his reputation, The Common Law.

In the continuing tug of war between democracy and liberty on the subject of race, Holmes generally chose not to choose. When possible - and the Court usually

193 Holmes-Pollock, supra note 5, at 1:252

194 Howe, supra note 16.

195 Id. at 268.

196 Benjamin Kaplan, Encounter with Oliver Wendell Holmes, Jr., 96 HaRv. L. Rev. 1828, 1840 (1983).

197 James Bradley Thayer, The Origin and Scope of the American Doctrine of Constitutional Law, 7 Harv. L. Rev.129, 144 (1893).

198 E.g., Lochner, supra note 170; Adair v. United States, 208 U.S. 161, 190 (1908); Coppage v. Kansas, 236 U.S. 28 (1915).

199 Holmes, supra note 99, at 1.

200 Southern. Pac. Co. v. Jensen, 244 U.S. 205, 217 (1917).

201 E.g. Lochner, supra note 143, at 76.

202 Oliver Wendell Holmes, Jr., The Path of the Law, 10 Harv. L. Rev. 457, 469 (1897). 
contrived to find it possible - he preferred a decision on some technical ground that forestalled consideration on the merits. What makes this odd is his renunciation of formalism. "No one will ever have a truly philosophical mastery over the law," he said at his Lowell lecture, "who does not habitually consider the forces outside of it which have made it what it is. . . the law finds its philosophy . . . in history and the nature of human needs." 203 If, as Judge Posner has written, "The character of legal formalism can be captured in such slogans as 'the law made me do it' or 'the law is its own thing," "204 this is precisely what the Court and Holmes himself did in case after case, as they turned back challenges on peonage, educational segregation, transportation segregation, and jury exclusion on narrow grounds. When the topic failed to interest him, Holmes' opposition to formalism was sometimes nowhere to be found.

Holmes' habitual self-restraint clearly frees him from the charge of having been cursed by a hunger for power. Yet he was plainly smitten by the claims of vanity, as was evident in his "striking," ${ }^{205}$ look-at-me appearance-the oldfashioned shirts and collars, the huge white moustache that nearly covered his mouth. As a former clerk put it, "He cut a dashing . . . figure." ${ }^{206}$ Holmes might not have concerned himself with the opinion of the rabble of the hoi polloi, but after two decades of unearned relative obscurity on a Massachusetts court, he very much wanted the approval of intellectuals - perhaps, the same kind of intellectuals he had encountered in childhood congregating around his father. As Wilson observed, "It is Holmes' special distinction . . . that he never dissociates himself from the great world of thought and art,"207 that is, from a realm inhabited not by the lawyers and law professors that normally follow judges, but by the larger intellectual community. Advancing causes well established in these circles, like free speech or government regulation of business, would earn him plaudits for his bold sagacity, and his dissents in these areas have become legendary. As one Progressive wrote, "No judge who has sat upon the bench has been more progressive in his outlook." 208

On the other hand, safeguarding the interests of blacks, whom these same intellectuals had all but forgotten, offered no comparable rewards. Holmes did not want Harlan's Don Quixote mantel, which offered in place of adulation merely the label of self-righteous troublemaker. "Deep seated preferences," he wrote, "cannot be argued about, ${ }^{209}$ and what preferences seemed more deep seated than racism? Yet if Holmes were unwilling to argue about this preference, he was more than willing to argue about deep seated preferences concerning free speech or government regulation of business. "Congress cannot forbid all efforts to change the mind of the country," he wrote in his much quoted Abrams dissent. ${ }^{210}$ Insisting that anti-

203 Oliver Wendell Holmes es, Jr., Review, in 3 Collected Works 103 (Sheldon M. Novick 1994).

204 Posner, supra note 190, at 4.

205 JefFrey \& Thomas E. O'Connell, Friendships aCross Ages: Johnson and Boswell, LASKi AND Holmes 76 (2008).

206 Paul Freund, Dark Equanimity, 59 Aм. ScHOL. 303 (1990).

207 WiLSON, supra note 28, at 781.

208 Charles Carpenter, Oliver Wendell Holmes, Jurist, 8 Ore. L. Rev. 269, 270 (1929).

209 Oliver Wendell Holmes, Jr., Natural Law, 32 HARv. L. Rev. 40, 41 (1918).

210 ABRAMs, supra note 175, at 628. 
peonage and jury exclusion legislation be enforced, however, was evidently a step too far. These preferences were left untouched.

Holmes, unsurprisingly, would have an answer to all this. "Belittling arguments," he once said, "have a force of their own," 211 which reminds us that all of us (and not merely Holmes) are radically imperfect. "Out of the crooked timber of humanity," in Kant's words, "no straight thing was ever made." 212 Holmes remains a towering figure in American law: it was Holmes who breathed life into the First Amendment, ${ }^{213}$ who battled liberty of contract ${ }^{214}$ and a constricted construction of the commerce clause, ${ }^{215}$ who modernized the takings clause, ${ }^{216}$ who gave inspiration ${ }^{217}$ to legal realism - and this impressive list is incomplete. Holmes was truly "a bridge between the old regime and the new order." ${ }^{18}$ On his retirement, Cardozo called him "the greatest of our age in the domain of jurisprudence; and one of the greatest of the ages." 219 Even a modern critic conceded "there is something grand about the man." 220 Yet Holmes failure to address the question of race with realism and compassion remains, beyond all doubt, a great stain on his reputation.

\footnotetext{
211 Holmes-Pollock, supra note 5, at 1: 223.

212 Immanuel Kant, Idea for a General History with a Cosmopolitan Purpose, Prop. 6 (1784).

213 SCHENCK, supra note 174.

214 LOCHNER, supra note 170.

215 Hammer, supra note 170.

216 Penn. Coal Co. v. Mahon, 250 U.S. 393 (1922).

$217{ }^{217}$ Karl N. Llewellyn, Legal Illusion, 31 CoLum. L. Rev. 82, 84 (1931).

218 David L. Faigman, Laboratory of Justice: The Supreme Court's 200 Year Struggle To InTEGRate ScIENCE AND LAW 82 (2005).

219 Benjamin N. Cardozo, Mr. Justice Holmes, 44 Harv. L. Rev. 682, 684 (1931).

220 Brenda Wineapple, Hardened by War: The Contradictions of Oliver Wendell Holmes, JR. Nation, Aug. 13, 2019.
} 